\title{
Pendugaan Analisis Kemanfaatan Tumpangsari Kacang Nasi (Vigna Angularis,L.) dan Jagung (Zea Mays L.) dalam Sistem Olah Lubang diperkaya Biochar dan Kompos
}

\author{
Andrinaris Bait Lake ${ }^{\mathrm{a}}$, dan Syprianus Ceunfin \\ ${ }^{a}$ Fakultas Pertanian, Universitas Timor, Kefamenanu, TTU - NTT, Indonesia, email: andrylake21@gmail.com \\ ${ }^{b}$ Fakultas Pertanian, Universitas Timor, Kefamenanu, TTU - NTT, Indonesia, email: ceunfins82@gmail.com
}

\section{Article Info}

\section{Article history:}

Received 13 Juni 2019

Received in revised form 4 Juli 2019

Accepted 16 Juli 2019

DOI:

https://doi.org/10.32938/sc.v4i02.744

Keywords:

Tumpangsari

Biochar

Kompos

Sistem Olah Lubang

Land Equivalent Ratio (LER)

\section{Pendahuluan}

Peningkatan jumlah penduduk setiap tahun berdampak terhadap kebutuhan pangan. Diperparah lagi dengan masifnya alih fungsi lahan mengakibatkan lahan pertanian menjadi berkurang. Persoalan lain pada sistem pertanian di daerah semi arid tropis adalah jumlah hari hujan yang relatif lebih rendah dari daerah lainnya. Musim hujan di TTU diketahui sangat pendek (3-4 bulan), dan mengalami musim kemarau panjang (8-9). Ini mengakibatkan perlunya perbaikan teknik budidaya dalam meningkatkan jumlah pangan pada sistem pertanian semi arid tropis sehingga peningkatan produktivitas pangan dapat tercapai. Minimnya curah hujan disiasati dengan sistem budidaya tanaman pangan cenderung monokultur. Salah satu teknik budidaya yang tepat digunakan wilayah TTU adalah sistem budidaya tumpang sari. Sistem tumpang sari yang diterapkan di kabupaten TTU berbeda dengan cara yang diterapkan secara nasional. Sistem tanam ini disebut $t$ sen bola' mese' atau salome (Levis dkk, 2017).

Salome adalah sistem tumpangsari antara jagung dengan beberapa jenis tanaman kacang-kacangan dalam lubang tanam yang sama pada waktu yang bersamaan.Tumpang sari adalah kegiatan penanaman dua atau lebih jenis tanaman yang berbeda spesies secara berdekatan pada unit lahan yang sama dalam waktu bersamaan maupun tidak, yang saling berinteraksi secara positif untuk meningkatkan hasil tanaman tersebut. Namun demikian sering muncul persoalan lain seperti terjadinya kompetisi terhadap sumberdaya (unsur hara, air, cahaya matahari dan ruang tumbuh). Agar tidak terjadi kompetisi terhadap sumberdaya maka perlu teknologi agar tidak terjadi kekurangan unsur hara dan air pada tanaman dengan menambahkan bahan organik kedalam tanah. Salah satu bahan organik yang memiliki potensi dalam mengikat air dan hara adalah biochar dan kompos. Biochar adalah merupakan arang hayati dari sebuah pembakaran tidak sempurna sehingga menyisakan unsur hara yang dapat menyuburkan lahan. Jika pembakaran berlangsung sempurna, biochar berubah menjadi abu dan melepaskan karbon yang nilainya lebih rendah (Gani, 2010). Proses pembuatan biochar bisa dilakukan secara tradisional, dimana hasil biocharnya dapat digunakan sebagai amandemen tanah (Lehmann dan Joseph, 2009; Lehmann dan Rondon, 2006). Sedangkan kompos merupakan bahan organik yang telah mengalami dekomposisi oleh mikroorganisme pengurai sehingga dapat dimanfaatkan untuk memperbaiki sifat-sifat tanah, disamping itu di dalam kompos terkandung hara-hara mineral yang berfungsi untuk penyediaan makanan bagi tanaman (Dharmawan, 2003).

Kompos merupakan bahan organik yang dapat berfungsi sebagai pupuk. Selain itu kompos juga dapat memperbaiki sifat fisik tanah sehingga tanah menjadi remah dan pada gilirannya mikroba-mikroba tanah yang bermanfaat dapat hidup lebih subur. Menurut Warsawa (2009), beberapa keuntungan pada pola tumpangsari antara lain: 1) akan terjadi peningkatan efisiensi (tenaga kerja, pemanfaatan lahan maupun penyerapan sinar matahari), 2) populasi tanaman dapat diatur sesuai bentuk dan ukuran lahan yang ingin dilakukan penanaman tumpangsari, 3) dalam satu areal lahan diperoleh produksi lebih dari satu komoditas, 4) tetap mempunyai peluang mendapatkan hasil jika satu jenis tanaman yang diusahakan gagal dan 5) kombinasi beberapa jenis tanaman dapat menciptakan beberapa jenis tanaman dapat menciptakan stabilitas biologis sehingga dapat menekan serangan hama dan penyakit serta mempertahankan kelestarian sumber daya lahan dalam hal ini kesuburan tanah.

Berdasarkan uraian latar belakang diatas maka peneliti tertarik untuk melakukan penelitian tentang "Analisis Kemanfaatan Tumpangsari Kacang Nasi (Vigna angularis L.) dan Jagung (Zea mays L.) dalam Sistem Olah Lubang diperkaya Biochar dan Kompos". Penelitian ini bertujuan untuk mengetahui keuntungan tumpangsari Kacang Nasi dan Jagung pada olah lubang, mengetahui hasil tumpang sari Jagung dan Kacang nasi pada pemberian biochar dan kompos pada olah lubang.

\section{Metode}

Penelitian ini dilaksanakan dikebun percobaan Fakultas Pertanian, Universitas Timor Kelurahan Sasi, Kecamatan Kota Kefamenanu, Kabupaten Timor Tengah Utara, Provinsi Nusa Tenggara Timur. Pelaksanaan penelitian ini meliputi persiapan lahan, pengaplikasian bahan pembenah tanah, penyortiran benih, penanaman, penyulaman, penjarangan, penyiangan dan panen. Penelitian lapangan ini menggunakan Rancangan Acak Kelompok (RAK) terdiri dari 2 faktorial dengan jumlah ulangan sebanyak 4 kali. Faktor pertama yakni jenis biochar terdiri dari 3 level : Biochar sekam padi $\left(\mathrm{B}_{1}\right) 160$ gr, Biochar serbuk gergaji $\left(\mathrm{B}_{2}\right) 160$ gr, Biochar kirinyuh $\left(\mathrm{B}_{3}\right) 160$ gr. Faktor kedua : Kompos $(\mathrm{K})$ terdiri dari 2 level yaitu: Tanpa kompos $\left(\mathrm{K}_{0}\right) 0 \mathrm{gr}$, kompos $\left(\mathrm{K}_{1}\right)$ 320gr. Dari level perlakuan tersebut kemudian dikombinasikan menjadi $\mathrm{K}_{0} \mathrm{~B}_{0}, \mathrm{~K}_{1} \mathrm{~B}_{0}, \mathrm{~K}_{0} \mathrm{~B}_{1}, \mathrm{~K}_{1} \mathrm{~B}_{1}, \mathrm{~K}_{1} \mathrm{~B}_{2}, \mathrm{~K}_{0} \mathrm{~B}_{2}, \mathrm{~K}_{0} \mathrm{~B}_{3}, \mathrm{~K}_{1} \mathrm{~B}_{3}$ yang diulang 4 kali sehingga terdapat 32 unit percobaan. Tata laksana diawali dengan persiapan lahan, persiapan bahan, pengaplikasian bahan pembenah tanah, penyortiran benih, penanaman, penyulaman dan pengamatan meliputi berat Jagung per hektar, berat kacang per hektar, land equivalen ratio, area time equivalend ratio, agresivity (A), coefisien croding, ratio competition, dan actual yield loss. Data hasil penelitian dianalisis menggunakan perangkat lunak (software) SAS for Windows 9.1 (SAS InstituteIn., USA). Data diuji lanjut pada tingkat nyata pada $\alpha$ $=5 \%$ menurut uji DMRT sesuai petunjuk Gomez dan Gomez (2010) Analisis data menggunakan program SAS 9.1 untuk mengetahui adanya interaksi antara perlakuan kompos dan perlakuan jenis biochar.

\section{Hasil dan Pembahasan \\ 3.1 Hasil}

\section{Berat Jagung Per Hektar}

Hasil sidik ragam (Anova) menunjukkan bahwa tidak terjadi interaksi antara perlakuan kompos dan jenis biochar terhadap parameter pengamatan berat Jagung per hektare. Pemberian kompos tanpa biochar $\left(\mathrm{B}_{0} \mathrm{~K}_{1}\right)$ memberikan berat Jagung tertinggi. Perlakuan kompos menunjukan beda nyata antar perlakuan terhadap berat Jagung per hektare. Berat Jagung per hektare dihasilkan oleh tanaman yang diberi kompos sebesar 1,13 t/ha dibanding tanaman yang tidak diberi kompos (Tabel 1).

Tabel 1. Berat Jagung Per Hektar ( $\mathrm{t} / \mathrm{ha})$

\begin{tabular}{cccccc}
\hline \multirow{2}{*}{ Takaran Kompos } & \multicolumn{4}{c}{ Jenis Biochar } & \multirow{2}{*}{ Rerata } \\
\cline { 2 - 5 } & B0 & B1 & B2 & B3 & \\
\hline K0 & 0.66 & 0.74 & 0.49 & 0.78 & $0.67 \mathrm{~b}$ \\
K1 & 1.64 & 1.10 & 0.82 & 0.94 & $1.13 \mathrm{a}$ \\
\hline Rerata & $1.15 \mathrm{a}$ & $0.92 \mathrm{ab}$ & $0.66 \mathrm{~b}$ & $0.86 \mathrm{ab}$ & $(-)$ \\
\hline
\end{tabular}

Keterangan : Angka pada baris dan kolom diikuti dengan huruf yang sama menunjukan beda pada tingkatnyata (a) $5 \%$ menurut uji DMRT.(-) Terjadi interaksi antar faktor, (-) tidak terjadi interaksi antar faktor

Faktor perlakuan jenis biochar menunjukan beda nyata antar perlakuan terhadap berat jagung per hektar dimana pada tanaman yang tidak diberi perlakuan biochar menghasilkan berat sebesar 1,15 ton/ha dibandingkan tanaman yang diberi perlakuan biochar.

\section{Berat Kacang Per Hektar}

Hasil sidik ragam (Anova) menunjukkan bahwa tidak terjadi interaksi antara perlakuan kompos dan jenis biochar terhadap parameter pengamatan berat kacang per hektare. Perlakuan kompos tanpa biochar $\left(\mathrm{B}_{0} \mathrm{~K}_{1}\right)$ memberikan 
hasil berat kacang per hektare tertinggi dibanding perlakuan lain. Pemberian kompos menunjukan beda nyata antar perlakuan terhadap berat kacang per hektare. Berat kacang per hektare yang tidak diberi perlakuan kompos menghasilkan berat sebesar $0,57 \mathrm{t} / \mathrm{ha}$ dibandingkan dengan tanaman yang diberi perlakuan kompos (Tabel 2)

Tabel 2. Berat Kacang Per Hektar (t/ha)

\begin{tabular}{|c|c|c|c|c|c|}
\hline \multirow[b]{2}{*}{ Takaran Kompos } & \multicolumn{4}{|c|}{ Jenis Biochar } & \multirow[b]{2}{*}{ Rerata } \\
\hline & B0 & $\mathrm{B} 1$ & $\mathrm{~B} 2$ & B3 & \\
\hline K0 & 0.55 & 0.63 & 0.42 & 0.68 & $0.57 \mathrm{~b}$ \\
\hline K1 & 1.49 & 0.96 & 0.67 & 0.76 & $0.97 \mathrm{a}$ \\
\hline Rerata & $1.02 \mathrm{a}$ & $0.80 \mathrm{ab}$ & $0.55 \mathrm{~b}$ & $0.72 \mathrm{ab}$ & $(-)$ \\
\hline
\end{tabular}

Keterangan : Angka pada baris dan kolom diikuti dengan huruf yang sama menunjukan beda pada tingkat nyata (a) $5 \%$ menurut uji DMRT. (-) Terjadi interaksi antar faktor, (-) tidak terjadi interaksi antar faktor.

Faktor perlakuan jenis biochar menunjukkan beda nyata antar perlakuan terhadap berat kacang per hektare dimana pada tanaman yang tidak diberi perlakuan biochar menghasilkan berat sebesar 1,02 ton/ha dibandingkan tanaman yang diberi perlakuan biochar serbuk gergaji yang paling rendah sebesar 0,55 ton/ha dari perlakuan biochar sekam padi dan biochar kirinyuh.

\section{Land Equivalent Ratio (LER)}

Hasil sidik ragam (Anova) menunjukkan bahwa tidak terjadi interaksi antar perlakuan kompos dan jenis biochar terhadap parameter LER. Pemberian kompos memberikan hasil beda nyata antar perlakuan terhadap LER. LER yang diberi perlakuan kompos memberikan hasil sebesar 6,86 dibandingkan dengan tanaman yang tidak diberi perlakuan kompos (Tabel 3).

\section{Tabel 3. Land Equivalent Ratio (LER)}

\begin{tabular}{|c|c|c|c|c|c|}
\hline \multirow{2}{*}{ Takaran Kompos } & \multicolumn{4}{|c|}{ Jenis Biochar } & \multirow{2}{*}{ Rerata } \\
\hline & B0 & $\mathrm{B} 1$ & B2 & B3 & \\
\hline $\mathrm{K} 0$ & 3.95 & 4.47 & 3.00 & 4.83 & $4.06 \mathrm{~b}$ \\
\hline K1 & 10.34 & 6.78 & 4.83 & 5.51 & $6.86 \mathrm{a}$ \\
\hline Rerata & $7.14 \mathrm{a}$ & $5.63 \mathrm{ab}$ & $3.92 \mathrm{~b}$ & $5.17 \mathrm{ab}$ & $(-)$ \\
\hline
\end{tabular}

Keterangan : Angka pada baris dan kolom diikuti dengan huruf yang sama menunjukan beda pada tingkat nyata (a) $5 \%$ menurut uji DMRT.(-) Terjadi interaksi antar faktor, (-) tidak terjadi interaksi antar faktor.

Faktor perlakuan jenis biochar menunjukkan beda nyata antar perlakuan terhadap Land Equivalent Ratio (LER) dimana pada tanaman yang tidak diberi perlakuan biochar menghasilkan berat paling tinggi sebesar $(7,14)$ dibandingkan tanaman yang diberi perlakuan biochar. Jenis biochar menunjukan beda nyata antar perlakuan namun pada perlakuan jenis biochar serbuk gergaji paling rendah sebesar $(3,92)$ dari jenis perlakuan biochar sekam padi dan biochar kirinyuh.

\section{Area Time Equivalend Racio (ATER)}

Hasil sidik ragam (Anova) menunjukkan bahwa tidak terjadi interaks antar perlakuan kompos dan jenis biochar terhadap parameter ATER. Perlakuan pemberian kompos menunjukkan beda nyata antar perlakuan. ATER dihasilkan oleh tanaman yang tidak diberi perlakuan kompos paling rendah sebesar $(2,52)$ dibandingkan tanaman yang diberi perlakuan kompos (Tabel 4).

Tabel 4. Area Time Equivalend Racio(ATER)

\begin{tabular}{cccccc}
\hline \multirow{2}{*}{ Takaran Kompos } & \multicolumn{4}{c}{ Jenis Biochar } & \multirow{2}{*}{ Rerata } \\
\cline { 2 - 5 } & B0 & B1 & B2 & B3 & \\
\hline K0 & 2.45 & 2.77 & 1.86 & 2.99 & $2.52 \mathrm{~b}$ \\
K1 & 6.40 & 4.20 & 3.00 & 3.42 & $4.25 \mathrm{a}$ \\
\hline Rerata & $4.42 \mathrm{a}$ & $3.49 \mathrm{ab}$ & $2.43 \mathrm{~b}$ & $3.20 \mathrm{ab}$ & $(-)$ \\
\hline
\end{tabular}

Keterangan : Angka pada baris dan kolom diikuti dengan huruf yang sama menunjukan beda pada tingkat nyata (a) $5 \%$ menurut uji DMRT. (-) Terjadi interaksi antar faktor, (-) tidak terjadi interaksi antar faktor

Faktor perlakuan jenis biochar menunjukan beda nyata antar perlakuan terhadap ATER dimana pada tanaman yang tidak diberi perlakuan jenis biochar menghasilkan nilai sebesar 4,42 dibandingkan dengan tanaman yang diberi perlakuan jenis biochar sekam padi, biochar serbuk gergaji dan biochar kirinyuh namun pada perlakuan serbuk gergaji memberikan hasil yang paling rendah dibandingkan dengan perlakuan lainnya.

\section{Ratio Crowding Coefficient (K) Jagung dan Kacang}

Hasil sidik ragam (Anova) menunjukkan tidak terjadi interaksi antar pemberian kompos dan jenis biochar terhadap parameter K. K pada Jagung dan Kacang untuk masing-masing faktor perlakuan memberikan nilai negatif. Ini menunjukkan koefisien kepadatan relatif $(\mathrm{K})$ tanaman Jagung dan Kacang tidak memberikan keuntungan sama sekali (Tabel 5).

\section{Agresivity (A) Jagung dan Kacang}

Agresifitas menunjukkan kompetisi antar tanaman dalam tumpang sari. Kompetisi antar tanaman akan muncul ketika dua jenis tanaman ditanam bersama-sama. Nilai yang tedapat pada agresifitas adalah sama namun dibedakan dengan tanda positif $(+)$ dan negatif (-). Palaniappan (1985) menyatakan bahwa jika nilai Agresivitas (A) $=0$ tanaman sama-sama kompetitif, $\mathrm{A}=+$ (positif) tanaman lebih dominan berkompetisi, $\mathrm{A}=$ - (negatif) tanaman kalah dalam berkompetisi. Hasil sidik ragam (Anova) menunjukkan bahwa terjadi interaksi antara perlakuan kompos dan jenis biochar terhadap parameter A. Tanaman Jagung yang diberi kompos tanpa biochar $\left(\mathrm{B}_{0} \mathrm{~K}_{1}\right)$ memberikan efek agresivity terbesar terhadap tanaman kacang (Tabel 6).

Tabel 5. Ratio Crowding Coefficient (K) Jagung dan Kacang

\begin{tabular}{ccccccc}
\hline & Takaran & \multicolumn{4}{c}{ Jenis Biochar } & \multirow{2}{*}{ Rerata } \\
\cline { 2 - 5 } Ratio Crowding & Kompos & B0 & B1 & B2 & B3 & \\
Coefficient (K) & K0 & -0.29 & -0.93 & -2.35 & -0.15 & -0.93 a \\
Jagung & K1 & -0.36 & -0.55 & -0.70 & -7.31 & -2.23 a \\
\cline { 2 - 6 } & Rerata & $-0.32 \mathrm{a}$ & $-0.74 \mathrm{a}$ & $-1.53 \mathrm{a}$ & $-3.73 \mathrm{a}$ & $(-)$ \\
\hline Ratio Crowding & $\mathrm{K} 0$ & -35.71 & -6.11 & -8.17 & -7.75 & $-14.43 \mathrm{a}$ \\
Coefficient $(\mathrm{K})$ & $\mathrm{K} 1$ & -4.68 & -5.21 & -6.22 & -6.01 & -5.53 \\
\cline { 2 - 5 } Kacang & Rerata & $-20.19 \mathrm{a}$ & $-5.66 \mathrm{a}$ & $-7.20 \mathrm{a}$ & $-6.88 \mathrm{a}$ & $(-)$
\end{tabular}

Keterangan : Angka pada baris dan kolom diikuti dengan huruf yang sama menunjukan beda pada tingkat nyata (a) $5 \%$ menurut uji DMRT.(-) Terjadi interaksi antar faktor, (-) tidak terjadi interaksi antar faktor.

Tabel 6.Agresivity (A) Jagung dan Kacang

\begin{tabular}{|c|c|c|c|c|c|c|}
\hline \multirow{4}{*}{$\begin{array}{c}\text { Agresivity (A) } \\
\text { Jagung }\end{array}$} & \multirow{2}{*}{$\begin{array}{l}\text { Takaran } \\
\text { Kompos }\end{array}$} & \multicolumn{4}{|c|}{ Jenis Biochar } & \multirow{2}{*}{ Rerata } \\
\hline & & B0 & B1 & B2 & B3 & \\
\hline & K0 & $0.02 \mathrm{bc}$ & $0.02 \mathrm{bc}$ & $0.01 \mathrm{c}$ & $0.03 \mathrm{bc}$ & 0.02 \\
\hline & $\mathrm{K} 1$ & $0.06 \mathrm{a}$ & $0.04 \mathrm{~b}$ & $0.02 \mathrm{bc}$ & $0.03 \mathrm{bc}$ & 0.04 \\
\hline & Rerata & $0.04 \mathrm{a}$ & $0.03 \mathrm{ab}$ & $0.02 \mathrm{~b}$ & $0.03 \mathrm{ab}$ & $(+)$ \\
\hline \multirow{3}{*}{$\begin{array}{c}\text { Agresivity (A) } \\
\text { Kacang }\end{array}$} & $\mathrm{K} 0$ & $-0.02 a b$ & $-0.02 a b$ & $-0.01 \mathrm{a}$ & $-0.03 a b$ & -0.02 \\
\hline & K1 & $-0.06 \mathrm{c}$ & $-0.04 b$ & $-0.02 \mathrm{ab}$ & $-0.03 \mathrm{ab}$ & -0.04 \\
\hline & Rerata & -0.04 & -0.03 & -0.02 & -0.03 & $(+)$ \\
\hline
\end{tabular}

Keterangan : Angka pada baris dan kolom diikuti dengan huruf yang sama menunjukan beda pada tingkat nyata (a) $5 \%$ menurut uji DMRT.(+) Terjadi interaksi antar faktor, (-) tidak terjadi interaksi antar faktor.

\section{Comptitive Ratio (RC) Jagung}

Hasil sidik ragam (Anova) menunjukkan bahwa tidak terjadi interaksi antara perlakuan kompos dan jenis biochar terhadap parameter RC. Pengamatan nilai rasio kompetisi jagung dan kacang menunjukkan kacang lebih kuat dalam berkompetisi dengan jagung dalam memperoleh sumber hara baik secara vertikal maupun horisontal. Hasil ini terbalik dengan nilai agresivity dari jagung terhadap kacang. Perlakuan kompos tanpa biochar $\left(\mathrm{B}_{0} \mathrm{~K}_{1}\right)$ memberikan nilai paling rendah pada tanaman Jagung yakni sebesar 0,11 dan nilai tertinggi pada tanaman kacang 28,31 (Tabel 7).

Tabel 7. Comptitive Ratio (RC) Jagung dan Kacang

\begin{tabular}{|c|c|c|c|c|c|c|}
\hline \multirow{5}{*}{$\begin{array}{c}\text { Comptitive } \\
\text { Ratio (RC) } \\
\text { Jagung }\end{array}$} & \multirow{2}{*}{$\begin{array}{l}\text { Takaran } \\
\text { Kompos }\end{array}$} & \multicolumn{4}{|c|}{ Jenis Biochar } & \multirow{2}{*}{ Rerata } \\
\hline & & B0 & B1 & B2 & B3 & \\
\hline & K0 & 0.12 & 0.12 & 0.12 & 0.11 & $0.12 \mathrm{a}$ \\
\hline & $\mathrm{K} 1$ & 0.11 & 0.11 & 0.13 & 0.13 & $0.12 \mathrm{a}$ \\
\hline & Rerata & $0.12 \mathrm{a}$ & $0.12 \mathrm{a}$ & $0.12 \mathrm{a}$ & $0.12 \mathrm{a}$ & $(-)$ \\
\hline Comptitive & $\mathrm{K} 0$ & 10.48 & 12.00 & 8.03 & 13.17 & $10.92 \mathrm{~b}$ \\
\hline Ratio(RC) & $\mathrm{K} 1$ & 28.31 & 18.33 & 12.78 & 14.59 & $18.50 \mathrm{a}$ \\
\hline
\end{tabular}

Keterangan : Angka pada baris dan kolom diikuti dengan huruf yang sama menunjukan beda pada tingkat nyata (a) $5 \%$ menurut uji DMRT.(-) Terjadi interaksi antar faktor, (-) tidak terjadi interaksi antar faktor

\section{Actual Yield Loss (AYL) Jagung}

Hasil sidik ragam (Anova) menunjukkan bahwa tidak terjadi interaksi antara perlakuan kompos dan jenis biochar terhadap parameter pengamatan (AYL). Jenis perlakuan tanpa kompos yang diaplikasi biochar serbuk gergaji memberikan nilai kehilangan hasil aktual Jagung sebesar $12 \%$. Penilaian kehilangan hasil aktual Jagung dan Kacang menunjukkan bahwa tanaman kacang sebagai tanaman sela memiliki nilai keuntungan sebesar 25.10-113,80 $\%$ (Tabel 8). Keuntungan tanaman Kacang terbesar terjadi pada perlakuan kompos tanpa diberi biochar $\left(\mathrm{B}_{0} \mathrm{~K}_{1}\right)$.

Tabel 8. Actual Yield Loss (AYL) Jagung dan Kacang

\begin{tabular}{ccccccc}
\hline & Takaran & \multicolumn{4}{c}{ Jenis Biochar } & \multirow{2}{*}{ Rerata } \\
\cline { 2 - 6 } Actual Yield Loss & Kompos & B0 & B1 & B2 & B3 & \\
\cline { 2 - 6 } (AYL) Jagung & K0 & 0.16 & 0.29 & -0.12 & 0.34 & $0.16 \mathrm{~b}$ \\
& K1 & 1.85 & 0.92 & 0.43 & 0.63 & $0.96 \mathrm{a}$ \\
\cline { 2 - 6 } & Rerata & $1.00 \mathrm{a}$ & $0.60 \mathrm{ab}$ & $0.15 \mathrm{~b}$ & $0.49 \mathrm{ab}$ & $\mathbf{( - )}$ \\
\hline \multirow{2}{*}{ Actual Yield Loss } & $\mathrm{K} 0$ & 3.58 & 4.25 & 2.51 & 4.76 & $3.77 \mathrm{~b}$ \\
(AYL) Kacang & $\mathrm{K} 1$ & 11.38 & 7.02 & 4.59 & 5.38 & $7.09 \mathrm{a}$ \\
\cline { 2 - 6 } & Rerata & $7.48 \mathrm{a}$ & $5.63 \mathrm{ab}$ & $3.55 \mathrm{~b}$ & $5.07 \mathrm{ab}$ & $\mathbf{( - )}$ \\
\hline
\end{tabular}

Keterangan : Angka pada baris dan kolom diikuti dengan huruf yang sama menunjukan beda pada tingkat nyata (a) $5 \%$ menurut uji DMRT.(-) Terjadi interaksi antar faktor (-) tidak terjadi interaksi antar faktor. 


\subsection{Pembahasan}

Efisiensi penggunaan lahan pada pola tumpangsari dapat dilihat melalui dua model persamaan yaitu Land Equivalent Ratio (LER) dan Area Time Equivalent Ratio (ATER). LER digunakan untuk memperkirakan pengaruh kompetisi dan keuntungan hasil dari sisi lahan sedangkan ATER digunakan untuk memperkirakan keuntungan hasil dari sisi waktu. Pola pertanaman tumpangsari jagung dan kacang nasi menunjukan nilai LER dan ATER $>1$. Hal ini menunjukan bahwa sistem tumpangsari pada olah lubang sangat cocok untuk diterapkan. Penelitian ini sejalan dengan penelitian Dahmardeh dkk., (2009) yang melakukan tumpang sari Jagung dengan $V$. unguiculata yang memiliki nilai LER sebesar 1,60-2,26. Ceunfins dkk., (2017) menyatakan bahwa nilai LER dan ATER pada tumpang sari Jagung dan Kacang kedelai berkisar antara 1,2 - 2,27 dan 1,2 - 2,2. Menurut (Yilmaz dkk.,2007) kenaikan hasil jagung umumnya merupakan konversi nitrogen yang dihasilkan oleh tanaman kacang yang ditumpangsarikan dengan jagung serta sistem perakaran dan tajuk tanaman jagung yang menyebar dan memiliki jangkauan yang luas untuk menyerap unsur hara dibandingkan dengan kacang yang perakarannya tidak menyebar dan tidak memiliki akar menyerap unsur hara dengan jangkauan yang luas. Hasil analisis sidik ragam menunjukkan bahwa tidak terjadi interaksi antar perlakuan pada semua parameter, kecuali pada parameter agresivity (A) tanaman Jagung dan Kacang. Agresivitas pada tanaman Jagung menunjukkan adanya dominasi pada tanaman Jagung dalam berkompetisi untuk memperoleh sumberdaya baik secara vertikal maupun secara horizontal. Tanaman yang kuat dalam berkompetisi akan memberikan hasil maksimal pada akhir siklus kehidupannya.

Hasil sidik ragam (Anova) menunjukkan bahwa tidak terjadi interaksi antara perlakuan kompos dan jenis biochar terhadap parameter rasio kompetisi Perlakuan kompos tanpa biochar $\left(\mathrm{B}_{0} \mathrm{~K}_{1}\right)$ memberikan nilai paling rendah pada tanaman Jagung yakni sebesar 0,11 dan nilai tertinggi pada tanaman Kacang 28,31. Pengamatan nilai rasio kompetisi Jagung dan Kacang menunjukkan Kacang lebih kuat dalam berkompetisi dengan Jagung dalam memperoleh sumber hara. Hasil ini terbalik dengan nilai agresivity dari Jagung terhadap Kacang. Nilai rasio kompetisi menguatkan agresifitas, bahwa semakin tinggi nilai agresifitas dalam sistem tumpangsari maka semakin kuat tanaman berkompetisi dalam memperoleh sumberdaya namun nilai agresifitas tanaman yang dihasilkan sangat kecil pada tanaman Jagung dan Kacang kalah dalam berkompetisi untuk memperoleh sumberdaya. Hasil penelitian menunjukan bahwa rasio kompetisi Jagung lebih tinggi dari tanaman Kacang pada perlakuan kompos dibandingkan pada perlakuan jenis biochar mengasilkan nilai rasio kompetisi sangat lebih tinggi. Pengamatan nilai rasio kompetisi Jagung dan Kacang menunjukkan Kacang lebih kuat dalam berkompetisi dengan Jagung dalam memperoleh sumber hara baik secara vertikal maupun horisontal. In diduga berkaitan dengan kemampuan kacang dalam berkompetisi mengambil cahaya untuk meningkatkan laju fotosintesis dan sistesis karbohidrat. Intensitas cahaya yang rendah akan mengakibatkan terganggunya laju fotosintesis dan sistesis sehingga terjadi penurunan laju pertumbuhan dan produktivitas kacang.

Ratio Crowding Coefficien (K) atau koefisien kepadatan relatif menunjukan bahwa tanaman Jagung dan Kacang tidak memberikan keuntungan sama sekali karena memiliki nilai negatif $(-)$ dan tanaman Jagung $\left(\mathrm{B}_{0} \mathrm{~K}_{1}\right)$ menunjukan nilai $-0,36$ sedangkan Kacang -4,68. Hasil penelitian menunjukan tidak adanya keuntungan pada tumpangsari bila dilihat dari koefisien kepadatan relatif. Menurut (Yilmaz dkk, 2007) menyatakan bahwa koefisien kepadatan relatif adalah ukuran dominasi dari satu spesies yang ditumpangsarikan. Ceunfins dkk.,(2017) melaporkan bahwa tumpang sari jagung dengan kacang kedelai memberikan hasil positif untuk tanaman kacang kedelai. Hasil sidik ragam (Anova) menunjukkan bahwa tidak terjadi interaksi antara perlakuan kompos dan jenis biochar terhadap parameter pengamatan (AYL). Jenis perlakuan tanpa kompos yang diaplikasi biochar serbuk gergaji memberikan nilai kehilangan hasil aktual jagung sebesar $12 \%$. Penilaian kehilangan hasil aktual Jagung dan Kacang menunjukkan bahwa tanaman Kacang sebagai tanaman sela memiliki nilai keuntungan sebesar $25.10-113,80 \%$. Keuntungan tanaman Kacang terbesar terjadi pada perlakuan kompos tanpa diberi biochar $\left(\mathrm{B}_{0} \mathrm{~K}_{1}\right)$. Hasil penelitian menunjukkan bahwa tanaman paling banyak mengalami kehilangan hasil pada tumpangsari adalah Jagung pada perlakuan tanpa kompos sebesar 0,16 sampai 0,34 atau setara dengan $16 \%$ sampai $34 \%$ dan pada perlakuan kompos 1,85 sampai 0,63 atau setara dengan $185 \%$ sampai $63 \%$. Tanaman Kacang Nasi tidak mengalami kehilangan hasil karena menghasilkan nilai yang sangat tinggi dan bernilai posetif. Penelitian ini sejalan dengan penelitian Ceunfins dkk., (2017) pada tumpangsari Jagung dan Kacang Kedelai nilai kehilangan hasil atau keuntungan pada tumpangsari adalah sebesar $-8,31$ sampai $-0,48$ atau setara dengan $83,1 \%$ sampai $48 \%$.

Hasil penelitian menunjukkan bahwa pada perlakuan tanpa biochar $\left(\mathrm{B}_{0} \mathrm{~K}_{1}\right)$ memberikan hasil terbaik karena tanah dalam memberikan sumber daya hara pada tanaman sudah mampu untuk menumbuhkan dan mampu memberikan hasil yang baik hanya dengan menggunakan perlakuan tanpa biochar (Lehmann dan Rondon, 2006). Kompos merupakan bahan organik yang telah mengalami dekomposisi oleh mikro organisme pengurai sehingga dapat dimanfaatkan untuk memperbaiki sifat-sifat tanah, disamping itu di dalam kompos terkandung hara-hara mineral yang berfungsi untuk penyediaan makanan bagi tanaman (Dharmawan, 2003). Kompos merupakan bahan organik yang dapat berfungsi sebagai pupuk, selain itu kompos juga dapat memperbaiki sifat fisik tanah sehingga tanah menjadi remah dan pada gilirannya mikroba- mikroba tanah yang bermanfaat dapat hidup lebih subur. Efek perlakuan kompos tanpa biochar $\left(\mathrm{B}_{0} \mathrm{~K}_{1}\right)$ yang memberikan nilai produktivitas tanaman tumpang sari yang lebih baik dibanding perlakuan lainnnya diduga karena pemberian kompos tanpa biochar lebih mudah dan cepat diserap oleh akar tanaman dibanding perlakuan kompos yang diberi biochar karena unsur hara masih diikat oleh biochar sehingga dilepas secara perlahan-lahan yang akhirnya berefek pada pertumbuhan dan produktivitas tanaman. Produktivitas tanaman berkaitan dengan hasil besarnya fotosintat yang diakumulasikan kebiji Jagung dan Kacang. Ketersediaan hara dari kompos pada perlakuan tanpa biochar memungkinkan akar tanaman lebih cepat menggunakan hara yang mendukung pertumbuhan tanaman menjadi optimal sehingga berefek pada besarnya fotosintat yang diakumulasikan.

\section{Simpulan}

Takaran kompos berpengaruh terhadap semua parameter pengamatan kecuali coefisien croding, racio competion Jagung. Perlakuan kompos pada olah lubang memberikan nilai LER dan ATER $\geq 1$. Jenis biochar berpengaruh nyata terhadap semua parameter pengamatan kecuali coefisien croding dan racio competion Jagung. Jenis biochar juga memberikan nilai LER dan ATER

$\geq 1$. Tumpangsari yang dilakukan didalam olah lubang antara Jagung dan Kacang Nasi dengan perlakuan jenis biochar dan kompos memberikan nilai LER dan ATER $\geq 1$

\section{Pustaka}

Ceunfins, S., Prajitno, D., Suryanto, P. \& Putra, E.T.S. 2017. Penilaian Kompetisi dan Keuntungan Hasil Tumpangsari Jagung di Bawah Tegakan Kayu Putih. Savana Cendana, 2(01): 1-3.

Dahmardeh, M., Ghanberi, A., Syasar, B., Ramroudi, M. 2009. Effect of intercropping maize (Zea mays L.) with cow pea (Vigna unguiculata L.) on green forage yield and quality evaluation. Asian journal of plant sciences. 8 (3): 235-239.

Dharmawan IW. 2003. Pemanfaatan endomikoriza dan pupuk organik dalam memperbaiki pertumbuhan Gmelina arborea LINN pada tanah tailing [Tesis]. Bogor: Program Pasca Sarjana. Institut Pertanian Bogor

Gani. 2010. Potensi Arang Hayati Biochar sebagai Komponen Teknologi Perbaikan Produktivitas Lahan Pertanian. Jurnal Iptek Tanaman Pangan Vol. 4 No. 1 - 2009.

Gomez, K.A. \& Gomez, A.A. 1984. Statistical Procedures for Agricultural Research. New York: John Wiley \& Sons.

Levis, L. R., K. Sukesi, Sugiyanto \& Y. Yuliati. 2017. Farmers Behaviour Regarding Food Security By Practicing The 'Salome' Farming System As Local Wisdom In West Timor, East Nusa Tenggara Province, Indonesia. Tropical and Subtropical Agroecosystems, 20(2017): 231 236.

Lehmann, J. and M. Rondon. 2006. Biochar soil management on highly weathered soils in the humid tropics. p: 51 7-530 In Biological Approaches to Sustainable Soil Systems (Norman Uphoff et al Eds.). Taylor \& Francis Group PO Box 409267 Atlanta, GA 30384-9267.

Lehmann, J. and S. Joseph. 2009. Biochar for environmental management: an introduction. science and technology. In: Lehmann and Joseph (Eds.). First published by Earthscan in the UK and USA in 2009.

Palaniappan. 1985. Cropping system in the Tropic: Prinsiples and Management. Coimbataro: Wiley Eastern Limited and Tamil Nadu Agricultural University. Tsay, J. 1985.

Warsawa 2009. Introduksi Teknologi Tumpangsari Jagung dan Kacang Tanah. Tabloid Sinar Tani. 25 Feb.

Yilmaz, F., M. Atak, \& M. Erayman. 2008. Identification of Advantages of Maize-Legume Intercropping over Solitary Cropping through Competition Indices in the East Mediterranean Region.Turk J. Agric 32: 111-119.0. 